\title{
Volatiles Emission by Crotalaria nitens after Insect Attack
}

\author{
Fausto Prada ${ }^{1,2}$, Elena E. Stashenko ${ }^{1,2, * \mathbb{D}}$ and Jairo René Martínez ${ }^{1,2}$ \\ 1 Center for Chromatography and Mass Spectrometry (CROM-MASS), Universidad Industrial de Santander, \\ Bucaramanga 680002, Colombia; fausto.prada@correo.uis.edu.co (F.P.); jmartine@uis.edu.co (J.R.M.) \\ 2 Colombia Research Center for Biomolecules (CIBIMOL), Universidad Industrial de Santander, \\ Bucaramanga 680002, Colombia \\ * Correspondence: elena@tucan.uis.edu.co
}

Citation: Prada, F.; Stashenko, E.E.; Martínez, J.R. Volatiles Emission by Crotalaria nitens after Insect Attack. Molecules 2021, 26, 6941. https:// doi.org/10.3390/molecules26226941

Academic Editors: Albert Lebedev and Gavino Sanna

Received: 15 September 2021

Accepted: 12 November 2021

Published: 17 November 2021

Publisher's Note: MDPI stays neutral with regard to jurisdictional claims in published maps and institutional affiliations.

Copyright: (c) 2021 by the authors. Licensee MDPI, Basel, Switzerland. This article is an open access article distributed under the terms and conditions of the Creative Commons Attribution (CC BY) license (https:// creativecommons.org/licenses/by/ $4.0 /)$.

\begin{abstract}
Plants are known to increase the emission of volatile organic compounds upon the damage of phytophagous insects. However, very little is known about the composition and temporal dynamics of volatiles released by wild plants of the genus Crotalaria (Fabaceae) attacked with the specialist lepidopteran caterpillar Utetheisa ornatrix (Linnaeus) (Erebidae). In this work, the herbivore-induced plant volatiles (HIPV) emitted by Crotalaria nitens Kunth plants were isolated with solid phase microextraction and the conventional purge and trap technique, and their identification was carried out by GC/MS. The poly-dimethylsiloxane/divinylbenzene fiber showed higher affinity for the extraction of apolar compounds (e.g., trans- $\beta$-caryophyllene) compared to the Porapak ${ }^{\mathrm{TM}}-\mathrm{Q}$ adsorbent from the purge \& trap method that extracted more polar compounds (e.g., trans-nerolidol and indole). The compounds emitted by $C$. nitens were mainly green leaf volatile substances, terpenoids, aromatics, and aldoximes (isobutyraldoxime and 2-methylbutyraldoxime), whose maximum emission was six hours after the attack. The attack by caterpillars significantly increased the volatile compounds emission in the C. nitens leaves compared to those subjected to mechanical damage. This result indicated that the $U$. ornatrix caterpillar is responsible for generating a specific response in $C$. nitens plants. It was demonstrated that HIPVs repelled conspecific moths from attacked plants and favored oviposition in those without damage. The results showed the importance of volatiles in plant-insect interactions, as well as the choice of appropriate extraction and analytical methods for their study.
\end{abstract}

Keywords: aldoximes; Crotalaria nitens; herbivore-induced plant volatiles; purge \&amp; trap; solidphase microextraction; Utetheisa ornatrix

\section{Introduction}

The coevolutionary process has allowed plants to biosynthesize a great diversity of secondary metabolites that reduce the attack of herbivores [1,2]. Alkaloids, phenylpropanoids, and digestion inhibitors directly repel phytophagous insects [3,4], while herbivory-induced plant volatiles (HIPV) play an important role in the indirect defense of plants, attracting antagonistic natural enemies of herbivores [5,6]. Interactions at different trophic levels are becoming relevant as a phenomenon that shapes the distribution and abundance of plants and insects in natural ecosystems [7-9].

Plants of the genus Crotalaria (Fam. Fabaceae) or rattlepods, grow as weeds in plains and roadsides of the inter-Andean valleys [10], they produce pyrrolizidine alkaloids as a direct defense against generalist herbivores [11]. In 1982, Thomas Eisner reported for the first time that pyrrolizidine alkaloids from Crotalaria pallida were related to the chemical defense of the moth Utetheisa ornatrix (Linnaeus) (Lepidoptera: Erebidae) [12]. The insect can sequester, transform, and use these alkaloids without negative effects on the fitness of U. ornatrix [13-15]. Many specialist herbivores have physiological adaptations that allow them to tolerate toxins $[16,17]$. Previous reports $[18,19]$ showed that, under laboratory experiments, $U$. ornatrix caterpillars sequestered and accumulated more pyrrolizidine alkaloids from Crotalaria nitens Kunth than other species evaluated. However, the attack 
of the caterpillar had no effect on the concentration of these alkaloids in the leaves of C. nitens [19]. This result led to the hypothesis that volatiles may be involved in the interaction of $C$. nitens with $U$. ornatrix, and to our knowledge this appearance has not been evaluated in any species of the genus Crotalaria.

Knowledge about volatiles in plants, their regulation, biosynthesis, and ecological importance in ecosystems has increased considerably since they were first reported around thirty years ago $[8,9,20]$, especially due to their potential use as biological control tools in agricultural systems [21] by manipulating the behavior of insect pests or their natural enemies [22-24]. Therefore, it requires the development of sensitive extraction and analytical methods for their identification and analysis. The most common sampling method is the purge and trap (P\&T) of the volatiles in ad/absorbent materials $[25,26]$. However, solidphase microextraction (SPME), developed by Pawliszyn et al. [27] in the early '90s, has proven to be a valuable tool for the extraction of volatile compounds due to its sensitivity and simplicity of handling without the use of solvents [28]. The technique has recently been applied to the detection of HIPV in plant-insect interaction experiments [29]. Here, we compared the two methods-P\&T and SPME-for the extraction and identification of HIPV emitted by $C$. nitens leaves.

HIPVs can generate contrasting effects, repelling, or attracting conspecific adult herbivores. For instance, the lepidopteran moths Heliothis virescens (Fabricius) (Noctuidae) [30], Trichoplusia ni (Hübner) (Noctuidae) [31], and Manduca sexta (Linnaeus) (Sphingidae) [32] are repelled by HIPVs released by the attacks of their caterpillars, while other conspecific adult species are attracted to infested plants, such as the lepidoptera Epiphyas postvittana (Walker) (Tortricidae) [33], Busseola fusca (Fuller) (Noctuidae), Sesamia calamistis (Hampson) (Noctuidae), and Chilo partellus (C. Swinhoe) (Crambidae) [34]. However, it is unknown whether the moths of the specialist insect $U$. ornatrix are attracted to or repelled by the blend of HIPVs emitted by C. nitens.

The objective of this work was to determine the composition and temporal dynamics of HIPVs release in $C$. nitens leaves attacked by $U$. ornatrix caterpillars or injured by mechanical means. Sampling was performed by trapping the volatiles in the Porapak ${ }^{\mathrm{TM}}-\mathrm{Q}$ adsorbent in a conventional P\&T system and on a poly-dimethylsiloxane/ divinylbenzene (PDMS/DVB) fiber supported in an SPME system. The identification of the volatiles was carried out by GC/MS. We studied whether the HIPVs blend emitted by C. nitens could modify the oviposition behavior of conspecific adult moths. The present study contains the characterization of HIPVs emitted by C. nitens plants and demonstrates their importance in the interaction with the specialist moth $U$. ornatrix.

\section{Results}

\subsection{GC/MS Analysis of Volatile Compounds Isolated by SPME and PET}

Many plant species emit volatiles in response to biotic and abiotic factors. The volatiles emitted by $C$. nitens leaves attacked by $U$. ornatrix caterpillars were sampled by two methods, one with a PDMS/DVB fiber of $65 \mu \mathrm{m}$ (SPME) and the other using the P\&T system with $25 \mathrm{mg}$ of Porapak ${ }^{\mathrm{TM}}$ adsorbent. The GC/MS analysis of the volatiles allowed the identification of 21 compounds ( $>0.05 \%$ ) (Table 1 and Figure 1 ) belonging to the families of $\mathrm{C}_{6}$-fatty acid derivatives called green leaf volatiles (GLV), terpenoids, aromatic, and aldoximes.

The temporal release dynamics of HIPVs in C. nitens leaves was determined every hour during the first two hours of insect attack and every two hours, up to $10 \mathrm{~h}$, after removing the caterpillars (Figure 2). At the start of the attack, GLVs (cis-hex-3-enal, hexyl acetate, cis-hex-3-enyl acetate, and cis-hex-3-en-1-ol) and the homoterpene trans-4,8-dimethylnonatriene (DMNT) were mainly detected [35]. During this time, the SPME fiber extracted $86.9 \%$ of GLVs and $8.9 \%$ of terpenes, while $97.6 \%$ of the compounds were GLVs and only $1.4 \%$ were terpenoids, using the P\&T system. The SPME fiber isolated some terpenoids, such as, trans- $\beta$-ocimene $(2.9 \%)$, linalool $(0.4 \%), \alpha$-humulene $(0.09 \%)$, and germacrene $\mathrm{D}$ $(0.15 \%)$, not registered in the extract of the P\&T system. 


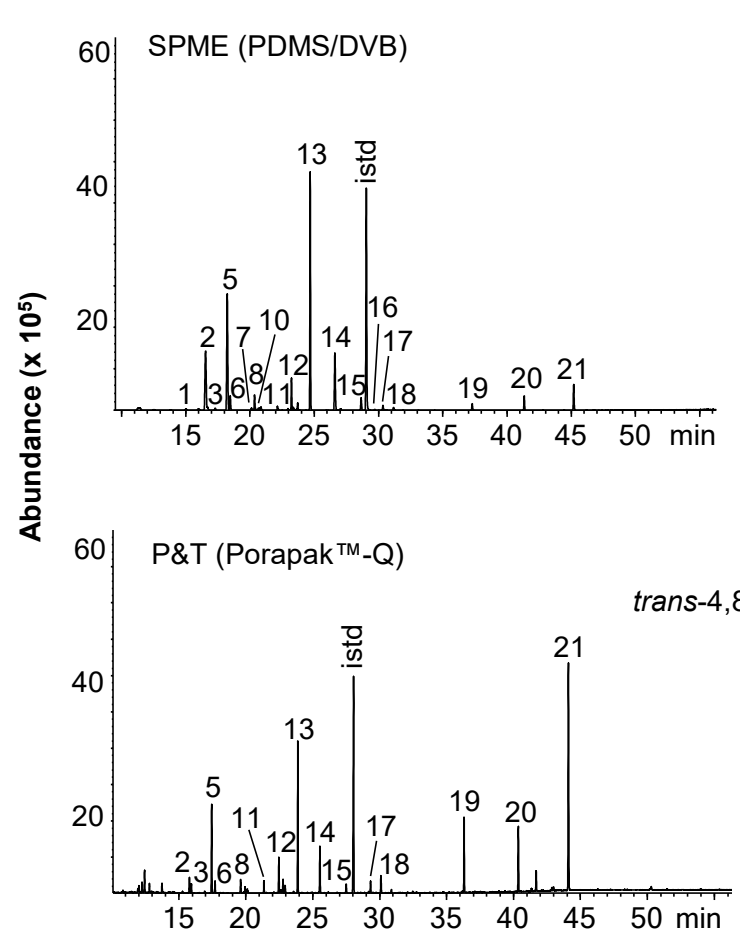

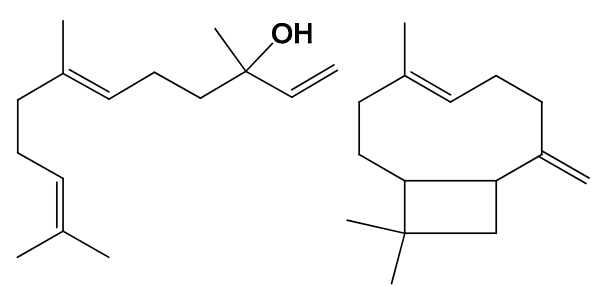

trans-Nerolidol
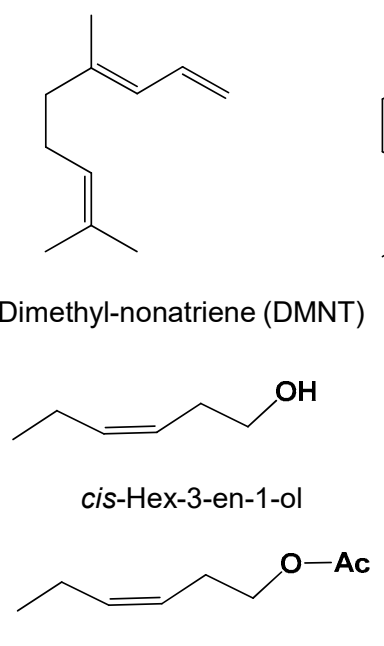

cis-Hex-3-enyl acetate<smiles>c1ccc2[nH]ccc2c1</smiles>

Indole

Figure 1. Chromatographic profiles of HIPVs emitted by $C$. nitens leaves and the chemical structure of the main volatile compounds. SPME (PDMS/DVB, $65 \mu \mathrm{m}$ ) and P\&T (Porapak ${ }^{\mathrm{TM}}-\mathrm{Q}$ ) sampling. GC/MS analysis (DB-WAX column, $60 \mathrm{~m}$ ). Table 1 contains peak identification; istd, methyl undecanoate.

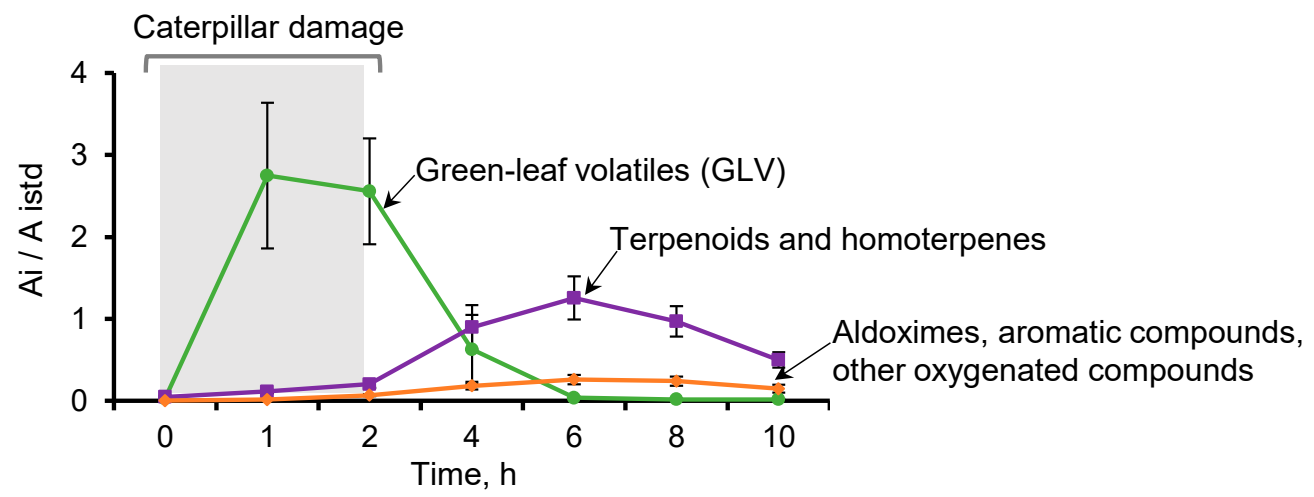

Figure 2. HIPV emission by $C$. nitens leaves attacked by U. ornatrix caterpillars. The caterpillars were fed for the first two hours, then removed from the plant. Volatiles were extracted using SPME. The ratio between the sum of areas of the group of compounds of interest $A_{i}$ and the area of the internal standard $\mathrm{A}_{\mathrm{istd}}$ (methyl undecanoate) is reported. Values are the mean \pm standard error $(n=7)$. 
Table 1. Identification of volatile organic compounds emitted during and after herbivory of C. nitens leaves.

\begin{tabular}{|c|c|c|c|c|c|c|c|c|c|}
\hline \multirow{3}{*}{ Peak $\mathbf{N}^{\circ}$ Figure 1} & \multirow{3}{*}{ Compound } & \multicolumn{2}{|c|}{ DB-WAX } & \multicolumn{2}{|c|}{ DB-5MS } & \multicolumn{4}{|c|}{ Relative GC Peak Area $(\%$, Mean \pm SE, $n=7)$} \\
\hline & & \multirow{2}{*}{$\begin{array}{c}\text { LRI } \\
\text { Experim. }\end{array}$} & \multirow{2}{*}{$\begin{array}{c}\text { LRI } \\
\text { Reported }\end{array}$} & \multirow{2}{*}{$\begin{array}{c}\text { LRI } \\
\text { Experim. }\end{array}$} & \multirow{2}{*}{$\begin{array}{c}\text { LRI } \\
\text { Reported }\end{array}$} & \multicolumn{2}{|c|}{ During the Attack (2 h) } & \multicolumn{2}{|c|}{ After the Attack (6 h) } \\
\hline & & & & & & SPME & P\&T & SPME & P\&T \\
\hline 1 & cis-Hex-3-enal $^{\text {a }}$ & 1140 & $1139[36]$ & 800 & 799 [36] & $0.2 \pm 0.10$ & $10.1 \pm 0.78$ & n.d. & n.d. \\
\hline 2 & trans- $\beta$-Ocimene ${ }^{a}$ & 1250 & $1250[36]$ & 1048 & $1048[36]$ & $2.9 \pm 0.76$ & n.d. & $14 \pm 4.2$ & $9 \pm 3.1$ \\
\hline 3 & 3-Octanone ${ }^{\mathrm{b}}$ & 1253 & $1255[36]$ & 986 & $985[36]$ & $1.8 \pm 0.45$ & $0.7 \pm 0.21$ & $1.1 \pm 0.32$ & $1.7 \pm 0.44$ \\
\hline 4 & Hexyl acetate ${ }^{b}$ & 1269 & $1264[37]$ & 1012 & $1010[36]$ & $0.5 \pm 0.17$ & $0.31 \pm 0.09$ & n.d. & n.d. \\
\hline 5 & trans-4,8-Dimethyl-nonatriene (DMNT) ${ }^{\mathrm{b}}$ & 1306 & $1302[38]$ & 1115 & 1119 [39] & $5 \pm 1.4$ & $1.2 \pm 0.31$ & $19 \pm 2.1$ & $8.9 \pm 0.93$ \\
\hline 6 & cis-Hex-3-enyl acetate ${ }^{a}$ & 1316 & 1308 [37] & 1004 & 1004 [36] & $80 \pm 3.8$ & $79 \pm 1.7$ & $1.9 \pm 0.54$ & $1.2 \pm 0.30$ \\
\hline 7 & allo-Ocimene $^{\mathrm{b}}$ & 1367 & $1366[36]$ & 1129 & $1130[36]$ & n.d. & n.d. & $0.18 \pm 0.08$ & n.d. \\
\hline 8 & Isobutyraldoxime ${ }^{a}$ & 1381 & - & 752 & - & n.d. & n.d. & $5 \pm 1.6$ & $3.4 \pm 0.73$ \\
\hline 9 & cis-Hex-3-en-1-ol a & 1384 & 1378 [36] & 855 & $857[36]$ & $6 \pm 1.7$ & $8 \pm 1.3$ & n.d. & n.d. \\
\hline 10 & 3-Octanol ${ }^{\mathrm{b}}$ & 1386 & $1392[36]$ & 998 & $993[36]$ & n.d. & n.d. & $0.14 \pm 0.09$ & n.d. \\
\hline 11 & Oct-1-en-3-ol a & 1448 & 1442 [36] & 982 & $980[36]$ & $1.2 \pm 0.35$ & n.d. & $0.7 \pm 0.23$ & $0.3 \pm 0.25$ \\
\hline 12 & 2-Methylbutyraldoxime ${ }^{b}$ & 1479 & - & 856 & - & n.d. & n.d. & $6 \pm 1.9$ & $5.3 \pm 0.73$ \\
\hline 13 & Linalool $^{\mathrm{a}}$ & 1543 & 1543 [36] & 1101 & 1099 [36] & $0.4 \pm 0.10$ & n.d. & $13 \pm 3.4$ & $11 \pm 1.4$ \\
\hline 14 & trans- $\beta$-Caryophyllene ${ }^{a}$ & 1610 & $1598[36]$ & 1422 & $1420[36]$ & $0.7 \pm 0.17$ & $0.12 \pm 0.07$ & $20 \pm 3.6$ & $13 \pm 2.4$ \\
\hline 15 & $\alpha$-Humulene ${ }^{\mathrm{a}}$ & 1683 & $1667[36]$ & 1471 & $1453[36]$ & $0.09 \pm 0.04$ & n.d. & $4.1 \pm 0.77$ & $3.1 \pm 0.55$ \\
\hline 16 & Germacrene $\mathrm{D}^{\mathrm{b}}$ & 1720 & 1708 [36] & 1492 & $1481[36]$ & $0.15 \pm 0.09$ & n.d. & $0.6 \pm 0.31$ & n.d. \\
\hline 17 & trans, trans- $\alpha$-Farnesene ${ }^{b}$ & 1746 & $1744[36]$ & 1505 & $1504[36]$ & n.d. & n.d. & $4 \pm 1.4$ & $8 \pm 2.5$ \\
\hline 18 & Methyl salicylate ${ }^{\mathrm{b}}$ & 1772 & $1768[36]$ & 1198 & $1193[36]$ & n.d. & n.d. & $0.3 \pm 0.15$ & $1.6 \pm 0.70$ \\
\hline 19 & trans-Nerolidol a & 2038 & $2036[36]$ & 1564 & $1561[36]$ & n.d. & n.d. & $1.4 \pm 0.30$ & $10 \pm 1.1$ \\
\hline 20 & Methyl anthranilate $\mathrm{b}$ & 2241 & 2255 [40] & - & - & n.d. & n.d. & $0.3 \pm 0.10$ & $3 \pm 1.5$ \\
\hline 21 & Indole ${ }^{\mathrm{a}}$ & 2446 & $2440[36]$ & 1300 & $1298[36]$ & $0.4 \pm 0.31$ & n.d. & $2.2 \pm 0.64$ & $18 \pm 4.4$ \\
\hline
\end{tabular}

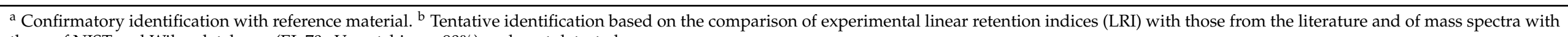
those of NIST and Wiley databases (EI, $70 \mathrm{eV}$, matching $>90 \%$ ). n.d., not detected. 
After two hours of attack, the release of GLVs was reduced to $1.9 \%$ and $1.2 \%$ measured by SPME and P\&T, respectively; however, the emission of terpenoids, aromatics, aldoximes, and other oxygenated compounds increased reaching a maximum at six hours. At this time, the proportion of terpenoids (mainly trans- $\beta$-ocimene, linalool, trans- $\beta$-caryophyllene, $\alpha$-humulene, trans, trans- $\alpha$-farnesene, and trans-nerolidol), including the homoterpene DMNT, raised their concentration to $77.2 \%$ and $63.7 \%$ extracted by SPME and P\&T methods, respectively. The aromatic compounds (methyl salicylate, methyl anthranilate and indole) were detected at 2.7\% (SPME) and 22.2\% (P\&T). The aldoximes isobutyraldoxime and 2-methylbutyraldoxime were extracted by the two methods at $11.5 \%$ (SPME) and $8.7 \%$ (P\&T). Such relatively simple oxime structures have been reported in approximately 22 different plant species [41]. Their identification was confirmed by mass spectra analysis and comparison of experimental data with those from the database (NIST, 2017) as shown in Figures S1 and S2. At six hours after the attack, the SPME fiber extracted other compounds, e.g., allo-ocimene $(0.18 \%)$, 3-octanol $(0.14 \%)$, and germacrene $\mathrm{D}(0.6 \%)$, that were not detected with the P\&T method.

The PDMS/DVB fiber adsorbed a higher proportion of nonpolar compounds (e.g., trans- $\beta$-ocimene, DMNT and trans- $\beta$-caryophyllene), while the adsorbent Porapak $^{\mathrm{TM}_{-} \mathrm{Q}}$ extracted a higher proportion of more polar compounds (e.g., trans-nerolidol, methyl salicylate, methyl anthranilate, and indole) (Table 1).

\subsection{Volatile Compounds from C. nitens after Either Mechanical Damage or Caterpillar Attack}

To determine if the volatiles emitted by $C$. nitens leaves was a specific response to the attack of the caterpillar, the compounds released after mechanically damaging the leaves with a scalpel were measured and compared with those compounds emitted after insect attack. The areas of damage done by both treatments were similar. Plants without attack only emit small amounts of DMNT (Figure 3). Soon after the mechanical damage, the leaves of $C$. nitens emitted the same GLVs (cis-hex-3-enyl acetate and cis-hex-3-en-1-ol) that they emitted after the insect attack. However, after two hours, the $C$. nitens leaves did not emit aromatic compounds and the emission of terpenoids and aldoximes decreased drastically compared to the volatile compounds emission made by the leaves after being damaged by the caterpillars.
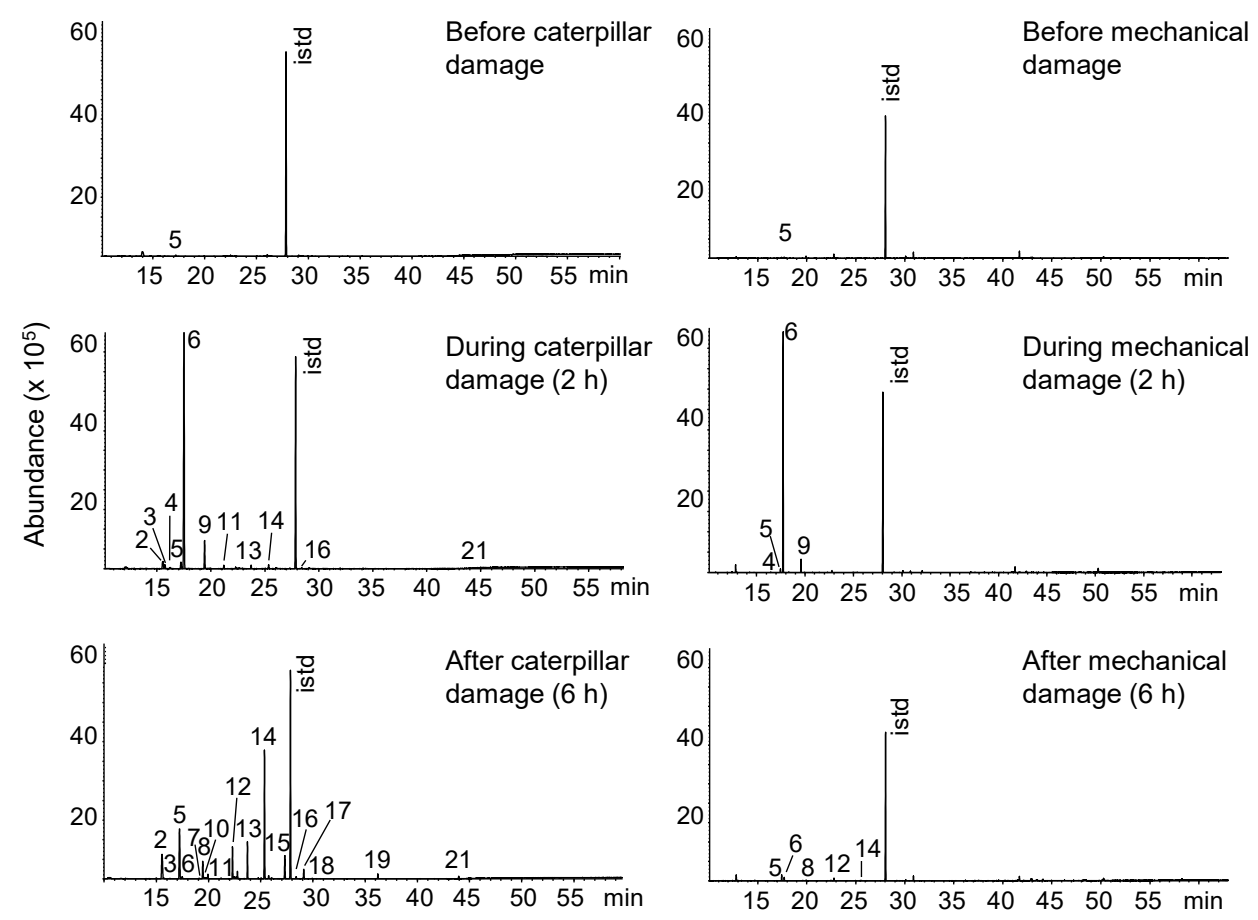

Figure 3. Volatile compounds released by $C$. nitens leaves after attack by U. ornatrix caterpillars or after mechanical damage. Peak identification appears in Table 1 ; istd, methyl undecanoate. 


\subsection{Conspecific Moths Repelled by Volatiles Induced by Herbivory with U. ornatrix Caterpillars}

Our results showed that $C$. nitens leaves emitted various GLVs, terpenoids, homoterpenes, aldoximes, and aromatic compounds after caterpillar attack, but not after mechanical damage. It has been reported that HIPVs can modify the herbivorous insect behavior [2] The last experiment showed that HIPVs emitted by $C$. nitens leaves, after the attack by the $U$. ornatrix caterpillars, repelled the conspecific female moths $(d f=12, \mathrm{t}=-4.05, p=0.0016$, Figure 4). The moths preferred to lay their eggs on undamaged plants rather than on those attacked by the caterpillars. During the $24 \mathrm{~h}$ of measurement, the five moths laid an average of 52 and 21 eggs on each undamaged and damaged plant, respectively. The moths from the control box having both undamaged plants showed in average 40 eggs/plant compared to the 21 eggs/plant in the control box with the two damaged plants.

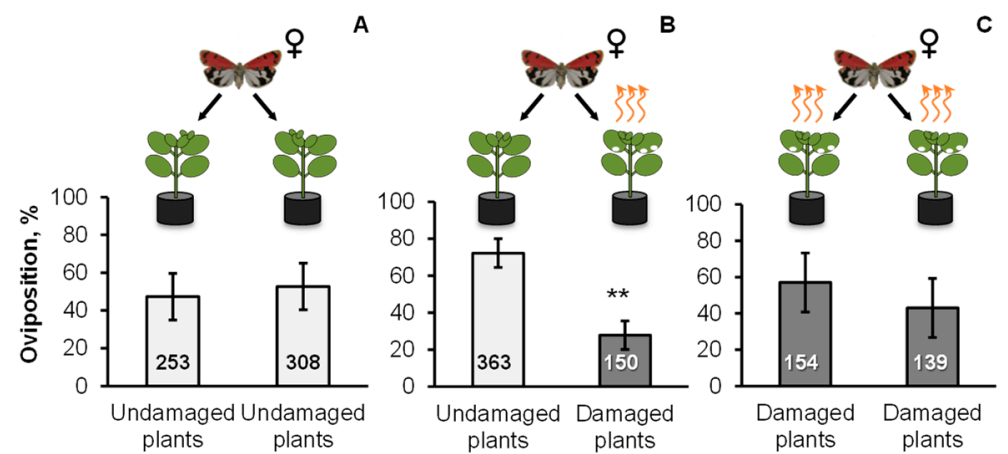

Figure 4. Oviposition preference of $U$. ornatrix female moths on $C$. nitens leaves. (A) On both sides of one carboard box were placed one undamaged plant. (B) On one side of a second box an undamaged plant was used and, on the other side, a plant that had been attacked by six third-instar caterpillars was included. (C) A third box contained two damaged plants. Welch's two sample $t$-test $(* * p<0.01)$. Values are the mean \pm standard error $(n=7)$. Each plant pair was used only once. Numbers included in bars correspond to the total number of eggs laid by moths across all replicates.

\section{Discussion}

The secondary metabolites produced by plants are important for their survival in all ecosystems, for adaptation to environmental changes and for ecological interactions with other organisms [4]. However, the identification and release dynamics of the volatiles emitted in Crotalaria genus plants in response to attack by herbivorous insects are still unknown [9]. In the present investigation, it was shown that $C$. nitens plants recognized the wound of the specialist caterpillar U. ornatrix and emitted HIPVs in response to its attack. To our knowledge, it is the first time that HIPVs are identified for a species of Crotalaria. The volatiles emitted by the leaves of $C$. nitens modified the behavior of $U$. ornatrix moths, significantly reducing their oviposition on previously attacked plants and preferring undamaged plants.

The volatiles released by plants play an important role in interactions with other organisms [2], therefore sensitive extraction methods are needed that accurately represent the mixture of compounds released [25,42]. In this work, we studied the volatiles emitted by C. nitens leaves by sampling with SPME and with a conventional P\&T system. Twentyone volatile compounds released by the $C$. nitens leaves were identified, belonging to the GLVs, terpenoid, homoterpene, aldoxime, and aromatic compound families. The sampling with the PDMS/DVB fiber was more sensitive and managed to isolate some terpene compounds that could not be detected in the extracts obtained by the P\&T extraction. The reason is that the SPME fiber allowed the analytes to be concentrated on the fiber and then desorbed directly into the injection port of the chromatographic system, whereas with the P\&T method, the compounds trapped in the sorbent were diluted with the extracting solvent before their analysis. The volatile compounds extraction using SPME was simpler to operate and did not require the use of solvents and therefore eliminated 
possible interferences and cross-contamination compared to the P\&T method. However, during the collection of HIPVs by SPME, the container accumulates moisture, and this condition can interfere with the physiological processes of the plant or the insect [25]. This problem did not occur with the P\&T method, due to the injection of filtered air into the system from the outside. However, the constant air flow increased the adsorption of pollutants that could not be retained by the activated carbon filters installed at the inlet of the system.

The $C$. nitens leaves emitted a wide variety of volatiles in response to the attack by the specialist caterpillar $U$. ornatrix. GLVs were the first compounds emitted by $C$. nitens leaves $[35,43]$. Subsequently, the terpenoids, the homoterpene DMNT, aldoximes, and aromatic compounds were released with a maximum emission at six hours after the attack. When the $C$. nitens leaves were subjected to mechanical damage, large amounts of GLVs were detected, but after two hours, the volatile emissions decreased dramatically compared to those generated upon insect attack. This result indicates that the $U$. ornatrix caterpillars were responsible for generating a specific response in $C$. nitens leaves. The ability of plants to distinguish types of damage, allows them to reduce the expenditure of valuable resources for defense in situations where it is not necessary. Some plants recognize the attack of the caterpillar by the presence of molecules such as volicitin or its derivatives, present in the oral secretion of Spodoptera exigua (Hübner) (Lepidoptera: Noctuidaese), which induce the emission of HIPVs from corn [44] or cotton [45] leaves. The results of the present study suggest that $C$. nitens plants distinguished the attack of the $U$. ornatrix caterpillars and activated a series of biochemical reactions that promoted volatile compounds release [1]. However, further research is required to determine whether the HIPVs induction was generated by specific molecules, enzymes, or microorganisms from the caterpillars' saliva.

The volatiles released by $C$. nitens leaves had been reported as herbivory-induced volatiles in other plants [46]. HIPVs are detected by insects to locate/avoid plants to use as oviposition sites [33,34,47]. In the present work, the blend of the HIPVs emitted by $C$. nitens leaves after the caterpillar wounding significantly reduced the oviposition of the conspecific moths in damaged plants $(28 \%)$ preferring to lay the eggs on those undamaged $(72 \%)$. These results were akin to those reported in other species of Lepidoptera. For instance, De Moraes et al. [30] observed that $H$. virescens moths selected non-infested tobacco plants (Nicotiana tabacum) to lay the eggs $(80 \%)$ and avoided the infested plants. The same behavior was registered for T. ni [31], M. sexta [32], Manduca quinquemaculata (Haworth) (Lepidoptera: Sphingidae) [2], or Spodoptera frugiperda (Smith) (Lepidoptera: Noctuidae) [48]. Changes in either the presence or relative abundance of the volatile compounds emitted by the plant upon caterpillar damage could have a completely different meaning for the moth, causing the plant not to be recognized as host [47]. Indeed, herbivoreinduced volatiles of $C$. nitens included linalool (11-13\%), an oxygenated monoterpene known to have oviposition-deterrent properties against many insect species $[2,49,50]$. trans$\beta$-Ocimene and DMNT, emitted by $C$. nitens leaves in relative amounts of $9-19 \%$, have shown to be repellents of stemborer moths, including Busseola fusca (Füller) (Lepidoptera: Noctuidae), and attractants of pest's natural enemies in the push-pull system in maize crops [23], and DMNT also deterred moths of the leaf worm, Spodoptera littoralis (Boisd.) (Lepidoptera: Noctuidae) from damaged plants of cotton (Gossypium hirsutum L.). The ability of moths to recognize changes in plant volatiles could have the benefit of avoiding host plants already infested with insects, which reduces the competition for food resources of their future offspring [30,47].

Other HIPVs identified in the present work have shown to be involved in the interaction between different organisms. GLVs, which first appeared due to herbivory or mechanical damage, have been reported in damaged leaves of maize seedlings [5,35], A. thaliana [51], cotton [52], and black poplar (Populus nigra) [53], among others. GLVs have ecological functions such as attracting or repelling insects [54], cis-hex-3-enyl acetate showed to increased herbivory defenses in maize [55] and activated defense genes in black poplar [56]. trans- $\beta$-Caryophyllene has been reported as repellent of Diaphorina citri, 
a bacteria-spreading insect in citrus crops [57], and to induce resistance against microbial pathogens in neighboring plants [58]. Linalool, trans- $\beta$-ocimene, DMNT, and methyl salicylate attracted female mite (Phtoseiulus persimilis), a natural predator of another mite (Tetranychus urticae), considered a pest in lima bean plants (Phaseolus lunatus) [59]. Although C. nitens emitted few amounts of allo-ocimene $(0.18 \%)$, this compound has shown antifungal properties in A. thaliana [60]. $\alpha$-Humulene reduced the mating ability of Ceratitis capitata females and males, a pest of various crops in the Mediterranean [61], and the trans-nerolidol was tested to induce resistance against herbivores and pathogens in tea plants [62].

The two most abundant HIPV families in C. nitens leaves were GLVs and terpenoids. However, C. nitens HIPVs also contained two aldoximes (isobutyraldoxime and 2-methylbutyraldoxime) in relative amounts of 9-11\%. Aldoximes are imine-type compounds derived from amino acids that have been reported as end products or intermediates to be further converted to nitriles and other metabolites [41]. Isobutyraldoxime and 2-methylbutyraldoxime are herbivore-induced compounds reported in Phaseolus vulgaris [41] and species of the genus Populus (Salicaceae) [63], among others. They are precursors of volatile nitriles in P. trichocarpa with repellent activity against the caterpillars Lymantria dispar (Lepidoptera: Erebidae) [64]. The 2- and 3-methylbutyraldoximes attracted the wasp Glyptapantheles liparidis, a parasitoid of the caterpillars L. dispar in P. nigra trees [65]. Regarding aromatic compounds, the leaves of $C$. nitens emitted methyl salicylate (0.3-1.6\%), methyl anthranilate $(0.3-3 \%)$, and indole (2-18\%). Methyl salicylate enhanced the growth of Lecanicillium lecanii, an entomopathogenic fungus, natural enemy of the aphid Lipaphis erysimi [66]. Methyl anthranilate, a naturally occurring volatile found in strawberries, reduced fungal growth that negatively affects fruit shelf life [67], and indole has been involved in plant-plant communication. It primmed the emission of volatiles (GLV and terpenoids) within the same plant and in neighboring plants that prepared them for future attacks by S. littoralis caterpillars [35].

Every HIPV compound emitted by $C$. nitens leaves has been reported to influence the ecological interactions of plants with other organisms. They can directly repel herbivores, serve as important foraging cues for natural enemies of the phytophagous insect, demonstrate antifungal activity, or prime non-attacked plant tissues and neighboring plants to respond more strongly to future attacks. Determining the single compound or blend of compounds emitted by $C$. nitens and associated with ecological functions might be a promising approach in this context. In this regard, the development and application of efficient methods for the extraction of target compounds, together with highly sensitive analytical instrumentation, become indispensable tools for a deep understanding of the ecological role of volatiles and their relevance in plant-insect interactions and the design of volatile-based agricultural strategies.

\section{Materials and Methods}

\subsection{Reagents}

cis-Hex-3-enal solution ( $>50 \%)$, the mixture of isomers cis-, and trans- $\beta$-ocimene $(>90 \%)$, cis-hex-3-enyl acetate $(>98 \%)$, isobutyraldoxime $(>80 \%)$, cis-hex-3-en-1-ol $(>98 \%)$, oct-1en-3-ol ( $>98 \%)$, linalool ( $>95 \%)$, trans- $\beta$-caryophyllene $(>98 \%), \alpha$-humulene $(>96 \%)$, transnerolidol $(>90 \%)$, indole $(>99 \%)$, and methyl undecanoate $(>99 \%)$ were obtained from SigmaAldrich (St. Louis, MO, USA or Steinheim, Germany). Methanol and dichloromethane were HPLC-grade from Merck (Darmstadt, Germany). The Porapak ${ }^{\mathrm{TM}}$-Q 80/100 mesh adsorbent was from Supelco (Bellefonte, PA, USA). The $\mathrm{C}_{6}-\mathrm{C}_{25} n$-alkanes mixture was purchased from AccuStandard, Inc. (New Haven, CT, USA). Helium (99.995\%) for GC analysis was acquired from Messer (Bucaramanga, Colombia).

\subsection{C. nitens Plants}

The seeds were collected from a natural population in the Andean mountains of the department of Santander, Colombia $\left(6^{\circ} 56^{\prime} 41.5^{\prime \prime} \mathrm{N}, 73^{\circ} 02^{\prime} 05.8^{\prime \prime} \mathrm{W}, 1144 \mathrm{~m}\right.$ above mean 
sea level), in June 2015. Botanical identification of C. nitens (voucher COL579431) was carried out at the National Herbarium of the Institute of Sciences at the National University of Colombia, Bogotá. A population of $C$. nitens plants was established in experimental plots of the CENIVAM research center. The $C$. nitens plants for the experiments were propagated in sand beds with daily irrigation and under natural conditions, after 15 days they were individually transplanted into pots $(1 \mathrm{~L})$ containing soil and rice chaff in a 7:3 ratio, respectively. The seedlings grew under greenhouse conditions with a relative humidity of $60 \pm 10 \%$, a temperature of $24 \pm 3{ }^{\circ} \mathrm{C}$ and a $12 \mathrm{~h}$ photoperiod. They were watered every two days and fertilized weekly with a solution $(\sim 50 \mathrm{~mL}, 1 \mathrm{~g} / \mathrm{L})$ of watersoluble fertilizer N-P-K-MgO: 11-27-12-2. Ten- to twelve-week-old plants were used for the experiments.

\subsection{U. ornatrix Caterpillars and Moths}

Approximately thirty caterpillars were collected from a natural population of Crotalaria spp. plants in Santander, Colombia (6 $6^{\circ} 9^{\prime} 49.1^{\prime \prime} \mathrm{N}, 73^{\circ} 22^{\prime} 11.4^{\prime \prime} \mathrm{W}, 299 \mathrm{~m}$ above mean sea level) in September 2018. The caterpillars were placed in a plastic container $(32 \mathrm{~cm} \times 28 \mathrm{~cm}$, $16 \mathrm{~cm}$ high) covered in tulle fabric. They were placed in an open room with air circulation, protected from rain and at room temperature $\left(18-26^{\circ} \mathrm{C}\right)$. The caterpillars were fed daily ad libitum with leaves or seeds of $C$. nitens from the culture previously established in the experimental plots. The pupae were carefully placed in butterfly houses constructed of cardboard boxes $(41 \mathrm{~cm} \times 41 \mathrm{~cm}, 60 \mathrm{~cm}$ high) covered with tulle fabric. When they emerged, the moths were fed twice a day with an aqueous solution of honey (5\%), according to the methodology of Martins et al. [68]. One-month-old C. nitens plants were placed inside the butterfly house for the moths to lay their eggs under their leaves. Eggs were collected daily and used to continue rearing $U$. ornatrix or to generate caterpillars and moths for experiments. The taxonomic identification showed a $99.9 \%$ similarity with $U$. ornatrix determined by COI gene sequencing [69]. The life cycle of $U$. ornatrix was similar to that described by Signoretti et al. [70]. The third or fourth instar caterpillars were brought to the laboratory $24 \mathrm{~h}$ before the experiments to allow their conditioning.

\subsection{Volatile Compound Emission by C. nitens Leaves}

To establish the variation in the emission of volatiles that occur in $C$. nitens leaves before, during and after the $U$. ornatrix caterpillars attack or after mechanical damage with a scalpel, $C$. nitens plants were randomly placed in setups for three treatments. Plants of the first group were subjected to the attack of $U$. ornatrix caterpillars $(6 /$ plant) for two hours [5]. Leaves $\mathrm{N}^{\circ} 4$ and $\mathrm{N}^{\circ} 5$ of the second group of plants were scraped on the surface with the scalpel (mechanical damage) similar to the area generated by the damage by the caterpillars [5,30]. Plants of the third group were used as a reference (control). Plants were transferred to the laboratory one day before the experiments. The volatiles emitted by C. nitens leaves were sampled by SPME and P\&T methods and analyzed by GC/MS.

\subsubsection{SPME Isolation of C. nitens Volatile Compounds}

The extraction of volatiles by SPME was carried out following the methodology described by Stashenko et al. [28], with modifications. One branch of each C. nitens plant $(n=7)$ with about ten leaves was placed inside a container $(10 \mathrm{~cm} \times 10 \mathrm{~cm} \times 10 \mathrm{~cm})$ made of acrylic material. The stem of the branch was protected with cotton so as not to hurt the plant when closing the system. The container had an attachment for inserting the SPME fiber holder (PDMS/DVB coated, $65 \mu \mathrm{m}$, Supelco, Bellefonte, PA, USA). The fiber was previously exposed $\left(5 \mathrm{~s}, 24^{\circ} \mathrm{C}\right)$, to the headspace of a flask $(2 \mathrm{~mL})$ containing methyl undecanoate ( $30 \mathrm{mg}$, internal standard), and then placed for $60 \mathrm{~min}$ in the headspace of the container. The volatiles were sampled at $1,2,4,6,8$, and $10 \mathrm{~h}$ from the start of the experiment (around 9:00 a.m.). Compounds trapped in the fiber were desorbed for $10 \mathrm{~min}$ at the injection port of a GC/MS (DB-WAX column, $60 \mathrm{~m}$ ). The acrylic container was flushed with methanol prior to each experiment and purged with nitrogen gas between 
measurements. Fiber, container, and plant blanks were performed prior to caterpillar attack or mechanical damage.

\subsubsection{P\&T Isolation of $C$. nitens Volatile Compounds}

The volatiles emitted by $C$. nitens leaves were measured in a multiple air supply system, as described by Erb et al. [35]. The assembly consisted of borosilicate glass bottles $50 \mathrm{~cm}$ high $\times 17 \mathrm{~cm}$ in diameter. The pots with the $C$. nitens plants $(n=7)$ were wrapped in aluminum foil. The plants were individually placed in each glass jar and hermetically sealed with a ground joint that was fastened on the outside with steel rings and screws. The air, previously purified with activated carbon filters, entered the containers at a speed of $1 \mathrm{~L} / \mathrm{min}$ and dragged the volatile compounds into the Porapak ${ }^{\mathrm{TM}}-\mathrm{Q}$ trap, at a speed of $0.8 \mathrm{~L} / \mathrm{min}$. The volatiles traps consisted of $7 \mathrm{~cm}$ glass tubes with $25 \mathrm{mg}$ of the adsorbent, which was held in place by a fine metal mesh on one side and some fiberglass supported by a piece of Teflon ( $2 \mathrm{~mm}$ long) in the other one. The traps were placed horizontally in one of the outlets at the top of each container. A hose ( $6 \mathrm{~mm}$ diameter) was connected to the volatiles trap and then to a vacuum pump through a flow regulator. The volatiles were sampled at hours 1, 2, 4, 6, 8, and 10 from the start of the experiment (around 9:00 a.m.).

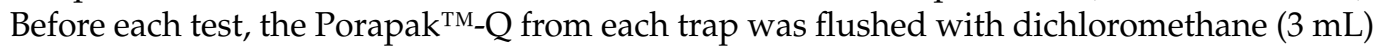
and blank samples of the container and plant were taken prior to caterpillar attack or mechanical damage. Immediately after removing the trap from the system, the compounds were eluted with dichloromethane $(150 \mu \mathrm{L})$ containing methyl undecanoate as an internal standard $(9.8 \mathrm{ng} / \mu \mathrm{L})$. The dichloromethane extract with the analytes was collected in glass inserts (0.2 mL, Supelco, Bellefonte, PA, USA) inside a chromatography vial and $2 \mu \mathrm{L}$ was injected into the GC/MS (DB-WAX column, $60 \mathrm{~m}$ ).

\subsection{GC/MS Analysis and Identification of C. nitens Volatile Compounds}

The identification of volatile compounds was based on chromatographic $\left(t_{R}\right.$ and LRI) and spectrometric (comparison of experimental mass spectra with those of databases and reference materials) criteria. A mixture of $\mathrm{C}_{6}-\mathrm{C}_{25} n$-alkanes was used for the determination of LRI, which followed the equation proposed by van Den Dool and Kratz [71]. Chromatographic data were obtained on DB-5MS ((J\&W Scientific, Folson, CA, USA) capillary columns of $60 \mathrm{~m} \times 0.25 \mathrm{~mm}$ id, coated with 5\% -phenyl-PDMS $(0.25 \mu \mathrm{m}, \mathrm{df}))$ and on a DB-WAX ((J\&W Scientific, Folson, CA, USA) of $60 \mathrm{mx} 0.25 \mathrm{~mm}$ id, coated with PEG $(0.25 \mu \mathrm{m}, \mathrm{df})$ following the procedure described previously [28]. The experimental values of the LRI were compared with those reported in the literature [36-40]. In all experiments, the chromatographic areas of the detected volatiles were used to calculate the relative abundances (relative GC area, \%) or the amount relative to that of the internal standard $\left(\mathrm{A}_{\mathrm{i}} / \mathrm{A}_{\mathrm{istd}}\right)$.

\subsection{U. ornatrix Oviposition on C. nitens}

It was evaluated whether the total mixture of HIPVs emitted by C. nitens, after the leaves were attacked by the caterpillar, can modify the behavior of $U$. ornatrix female moths. For this, their oviposition preference was determined on undamaged or caterpillar-attacked $C$. nitens plants. Two $C$. nitens plants were placed in a cardboard box $(60 \mathrm{~cm} \times 60 \mathrm{~cm} \times 60 \mathrm{~cm})$ covered with tulle fabric. On one side of the box, a plant without damage was placed, and on the other side, a plant that had been attacked for $2 \mathrm{~h}$ by six third-instar $U$. ornatrix caterpillars was included. The caterpillars were removed from the plant before moths were introduced. Five mated six-day-old female $U$. ornatrix moths were released into the box (around 11:00 a.m.). Two additional boxes were used as controls, testing the same oviposition preference; the first box contained two undamaged plants in opposite sides, and the second box had two caterpillar-damaged plants, obtained as described before. The three boxes were placed randomly and separated more than $5 \mathrm{~m}$ to avoid the effect of volatiles from the neighboring boxes. The moths were removed after $24 \mathrm{~h}$ and the eggs were counted on each plant. The experiment, including the three previously 
described boxes, was performed on different days $(n=7)$, depending on the availability of moths.

\section{Conclusions}

In this study, it was demonstrated that $C$. nitens plants recognized the attack of the caterpillar U. ornatrix by emitting HIPVs such as terpenoids, homoterpenes, aldoximes, and aromatic compounds that were not detected when their leaves suffered mechanical damage. GLVs were the first compounds to appear after insect wounding or mechanical damage. HIPVs modified the behavior of female $U$. ornatrix moths, reducing their oviposition on plants attacked by the caterpillars. Most of the HIPVs emitted by C. nitens leaves were reported to have ecological functions in other models of plant-insect interaction and even in plant-plant communication. The SPME sampling method was more sensitive and isolated some terpenes that were not detected by the conventional P\&T method. The present investigation contributed to the GC/MS chemical characterization of the compounds associated with the interaction between a Crotalaria species and its specialist herbivore $U$. ornatrix and demonstrated the capacity of volatile blends to modify the behavior of insects. More research is required to understand the intricate chemical and ecological interactions between plants, herbivores, and other organisms, which can be harnessed as tools for the protection of more sustainable and environmentally friendly agricultural systems.

Supplementary Materials: The following are available online, Figure S1: Mass spectra (EI, $70 \mathrm{eV}$ ) of A. The compound with LRI 1381 (DBWAX) detected in the volatiles emitted by C. nitens leaves after herbivory. B. Isobutyraldoxime reference compound (Sigma-Aldrich, Cat. \#S388378, CAS 151-00-8). C. Isobutyraldoxime from NIST, 2017 database. Figure S2: Mass spectra (EI, $70 \mathrm{eV}$ ) of A. The compound with LRI 1479 (DB-WAX) detected in the volatiles of $C$. nitens leaves after insect attack. B. 2-Methylbutyraldoxime (NIST, 2017). C. 3-Methylbutyraldoxime (NIST, 2017). Differences between isomeric aldoximes based on the McLafferty rearrangement typical products.

Author Contributions: Conceptualization, E.E.S. and F.P.; methodology, E.E.S. and F.P.; formal analysis, E.E.S. and F.P.; investigation, F.P.; resources, E.E.S., F.P. and J.R.M.; supervision, E.E.S. and J.R.M.; project administration, E.E.S.; funding acquisition, E.E.S. All authors have read and agreed to the published version of the manuscript.

Funding: This research was funded by the Ministry of Science, Technology and Innovation; the Ministry of Education; the Ministry of Industry, Commerce and Tourism; ICETEX, Programme Ecosistema Científico-Colombia Científica; and the Francisco José de Caldas Fund, Grant RC-FP44842-2122018; and the Universidad Industrial de Santander-VIE, Grant 2498.

Institutional Review Board Statement: Experiments that involved U. ornatrix manipulation were approved by the Ethics in Scientific Research Committee of Universidad Industrial de Santander, according to Act $\mathrm{N}^{\circ} 6,13$ April 2018. Genetic Resources Permits, $\mathrm{N}^{\circ} 101$ and $\mathrm{N}^{\circ} 270$, supported the plant collection (Contrato de acceso a recursos genéticos y productos derivados para investigación científica con fines de prospección biológica) with the Ministry for Environment and Sustainable Development.

Informed Consent Statement: Not applicable.

Data Availability Statement: Supporting data are included in the CIBIMOL research group data repository.

Acknowledgments: F.P. would like to thank the fellowship provided by Minciencias (Convocatoria Doctorados Nacionales 617/2013).

Conflicts of Interest: The authors declare no conflict of interest.

\section{References}

1. Mithöfer, A.; Boland, W.; Maffei, M.E. Chemical ecology of plant-insect interactions. In Molecular Aspects of Plant Disease Resistance; Parker, J., Ed.; Wiley-Blackwell: Chirchester, UK, 2009; Chapter 9; pp. 261-291.

2. Kessler, A.; Baldwin, I.T. Defensive function of herbivore-induced plant volatile emissions in nature. Science 2001, 291, 2141-2144. [CrossRef] 
3. Chen, M.S. Inducible direct plant defense against insect herbivores: A review. Insect. Sci. 2008, 15, 101-114. [CrossRef]

4. Mithöfer, A.; Boland, W. Plant defense against herbivores: Chemical aspects. Annu. Rev. Plant Biol. 2012, 63, 431-450. [CrossRef] [PubMed]

5. Turlings, T.C.; Tumlinson, J.H.; Lewis, W.J. Exploitation of herbivore-induced plant odors by host-seeking parasitic wasps. Science 1990, 250, 1251-1253. [CrossRef]

6. Kost, C.; Heil, M. Herbivore-induced plant volatiles induce an indirect defence in neighbouring plants. J. Ecol. 2006, 94, 619-628. [CrossRef]

7. Hopkins, R.J.; van Dam, N.M.; van Loon, J.J. Role of glucosinolates in insect-plant relationships and multitrophic interactions. Annu. Rev. Entomol. 2009, 54, 57-83. [CrossRef]

8. Turlings, T.C.; Erb, M. Tritrophic interactions mediated by herbivore-induced plant volatiles: Mechanisms, ecological relevance, and application potential. Annu. Rev. Entomol. 2018, 63, 433-452. [CrossRef]

9. Bouwmeester, H.; Schuurink, R.C.; Bleeker, P.M.; Schiestl, F. The role of volatiles in plant communication. Plant J. 2019, 100, 892-907. [CrossRef]

10. Bernal, R.; Gradstein, S.R.; Celis, M. Catálogo de Plantas y Líquenes de Colombia; Instituto de Ciencias Naturales, Universidad Nacional de Colombia: Bogotá, Colombia, 2019; Available online: http:/ / catalogoplantasdecolombia.unal.edu.co (accessed on 15 November 2021).

11. Trigo, J.R. Effects of pyrrolizidine alkaloids through different trophic levels. Phytochem. Rev. 2011, 10, 83-98. [CrossRef]

12. Eisner, T. For love of nature: Exploration and discovery at biological field stations. BioScience 1982, 32, 321-326. [CrossRef]

13. Hartmann, T. Chemical ecology of pyrrolizidine alkaloids. Planta 1999, 207, 483-495. [CrossRef]

14. Cogni, R.; Trigo, J.R. Pyrrolizidine alkaloids negatively affect a generalist herbivore feeding on the chemically protected legume Crotalaria pallida. Neotrop. Entomol. 2016, 45, 252-257. [CrossRef] [PubMed]

15. Cogni, R.; Trigo, J.R.; Futuyma, D.J. A free lunch? No cost for acquiring defensive plant pyrrolizidine alkaloids in a specialist arctiid moth (Utetheisa ornatrix). Mol. Ecol. 2012, 21, 6152-6162. [CrossRef] [PubMed]

16. Ali, J.G.; Agrawal, A.A. Specialist versus generalist insect herbivores and plant defense. Trends Plant Sci. 2012, 17, 293-302. [CrossRef]

17. Rowen, E.; Kaplan, I. Eco-evolutionary factors drive induced plant volatiles: A meta-analysis. New Phytol. 2016, 210, 284-294. [CrossRef]

18. Prada, F.; Stashenko, E.E.; Martínez, J.R. LC/MS study of the diversity and distribution of pyrrolizidine alkaloids in Crotalaria species growing in Colombia. J. Sep. Sci. 2020, 43, 4322-4337. [CrossRef]

19. Prada, F. Variación En El Contenido De Alcaloides Pirrolizidínicos Y Compuestos Orgánicos Volátiles En Crotalaria spp. (Fabaceae) Inducidos Por Herbivoría Con Utetheisa ornatrix (Lepidóptera). Ph.D.Thesis, Universidad Industrial de Santander, Bucaramanga, Colombia, 2020.

20. Dudareva, N.; Klempien, A.; Muhlemann, J.K.; Kaplan, I. Biosynthesis, function and metabolic engineering of plant volatile organic compounds. New Phytol. 2013, 198, 16-32. [CrossRef]

21. Ninkovic, V.; Markovic, D.; Rensing, M. Plant volatiles as cues and signals in plant communication. Plant Cell Environ. 2021, 44, 1030-1043. [CrossRef]

22. Cook, S.M.; Khan, Z.R.; Pickett, J.A. The use of push-pull strategies in integrated pest management. Annu. Rev. Entomol. 2007, 52, 375-400. [CrossRef]

23. Khan, Z.; Midega, C.A.; Hooper, A.; Pickett, J. Push-pull: Chemical ecology-based integrated pest management technology. J. Chem. Ecol. 2016, 42, 689-697. [CrossRef]

24. Mutyambai, D.; Bass, E.; Luttermoser, T.; Poveda, K.; Midega, C.A.; Khan, Z.R.; Kessler, A. More than 'Push' and 'Pull'? Plant-soil feedbacks of maize companion cropping increase chemical plant defenses against herbivores. Front. Ecol. Evol. 2019, 7, 217. [CrossRef]

25. Tholl, D.; Boland, W.; Hansel, A.; Loreto, F.; Röse, U.S.; Schnitzler, J.P. Practical approaches to plant volatile analysis. Plant J. 2006, 45, 540-560. [CrossRef] [PubMed]

26. Franchina, F.A.; Zanella, D.; Lazzari, E.; Stefanuto, P.H.; Focant, J.F. Investigating aroma diversity combining purge-and-trap, comprehensive two-dimensional gas chromatography, and mass spectrometry. J. Sep. Sci. 2020, 43, 1790-1799. [CrossRef]

27. Arthur, C.L.; Pawliszyn, J. Solid phase microextraction with thermal desorption using fused silica optical fibers. Anal. Chem. 1990, 62, 2145-2148. [CrossRef]

28. Stashenko, E.E.; Martínez, J.R.; Cárdenas-Vargas, S.; Saavedra-Barrera, R.; Durán, D.C. GC-MS study of compounds isolated from Coffea arabica flowers by different extraction techniques. J. Sep. Sci. 2013, 36, 2901-2914. [CrossRef] [PubMed]

29. Van Doan, C.; Züst, T.; Maurer, C.; Zhang, X.; Machado, R.A.; Mateo, P.; Ye, M.; Schimmel, B.C.; Glauser, G.; Robert, C.A. Herbivore-induced plant volatiles mediate defense regulation in maize leaves but not in maize roots. Plant Cell Environ. 2021, 44, 2672-2686. [CrossRef] [PubMed]

30. De Moraes, C.M.; Mescher, M.C.; Tumlinson, J.H. Caterpillar-induced nocturnal plant volatiles repel conspecific females. Nature 2001, 410, 577-580. [CrossRef] [PubMed]

31. Landolt, P.J. Effects of host plant leaf damage on cabbage looper moth attraction and oviposition. Entomol. Exp. Appl. 1993, 67, 79-85. [CrossRef] 
32. Reisenman, C.E.; Riffell, J.A.; Duffy, K.; Pesque, A.; Mikles, D.; Goodwin, B. Species-specific effects of herbivory on the oviposition behavior of the moth Manduca sexta. J. Chem. Ecol. 2013, 39, 76-89. [CrossRef]

33. El-Sayed, A.M.; Knight, A.L.; Byers, J.A.; Judd, G.J.; Suckling, D.M. Caterpillar-induced plant volatiles attract conspecific adults in nature. Sci. Rep. 2016, 6, 37555. [CrossRef]

34. Sokame, B.M.; Ntiri, E.S.; Ahuya, P.; Torto, B.; Le Ru, B.P.; Kilalo, D.C.; Juma, G.; Calatayud, P.A. Caterpillar-induced plant volatiles attract conspecific and heterospecific adults for oviposition within a community of lepidopteran stemborers on maize plant. Chemoecology 2019, 29, 89-101. [CrossRef]

35. Erb, M.; Veyrat, N.; Robert, C.A.; Xu, H.; Frey, M.; Ton, J.; Turlings, T.C. Indole is an essential herbivore-induced volatile priming signal in maize. Nat. Commun. 2015, 6, 6273. [CrossRef] [PubMed]

36. Babushok, V.I.; Linstrom, P.J.; Zenkevich, I.G. Retention indices for frequently reported compounds of plant essential oils. J. Phys. Chem. Ref. Data 2011, 40, 43101. [CrossRef]

37. Ruther, J. Retention index database for identification of general green leaf volatiles in plants by coupled capillary gas chromatography-mass spectrometry. J. Chromatogr. A 2000, 890, 313-319. [CrossRef]

38. Buttery, R.G.; Light, D.M.; Nam, Y.; Merrill, G.B.; Roitman, J.N. Volatile components of green walnut husks. J. Agric. Food Chem. 2000, 48, 2858-2861. [CrossRef]

39. Borges, E.D.O.; Martins, C.B.; da Silva, R.R.; Zarbin, P.H. Terpenoids dominate the bouquet of volatile organic compounds produced by Passiflora edulis in response to herbivory by Heliconius erato phyllis (Lepidoptera:Nymphalidae). Arthropod-Plant Int 2018, 12, 123-131. [CrossRef]

40. Ferreira, V.; Aznar, M.; Lopez, R.; Cacho, J. Quantitative gas chromatography-olfactometry carried out at different dilutions of an extract. Key differences in the odor profiles of four high-quality Spanish aged red wines. J. Agric. Food Chem. 2001, 49, 4818-4824. [CrossRef]

41. Sørensen, M.; Neilson, E.H.; Møller, B.L. Oximes: Unrecognized chameleons in general and specialized plant metabolism. Mol. Plant 2018, 11, 95-117. [CrossRef]

42. Stashenko, E.E.; Martínez, J.R. Sampling flower scent for chromatographic analysis. J. Sep. Sci. 2008, 31, 2022-2031. [CrossRef]

43. Scala, A.; Allmann, S.; Mirabella, R.; Haring, M.A.; Schuurink, R.C. Green leaf volatiles: A plant's multifunctional weapon against herbivores and pathogens. Int. J. Mol. Sci. 2013, 14, 17781-17811. [CrossRef]

44. Alborn, H.T.; Turlings, T.C.J.; Jones, T.H.; Stenhagen, G.; Loughrin, J.H.; Tumlinson, J.H. An elicitor of plant volatiles from beet armyworm oral secretion. Science 1997, 276, 945-949. [CrossRef]

45. Arce, C.M.; Besomi, G.; Glauser, G.; Turlings, T.C.J. Caterpillar-induced volatile emissions in cotton: The relative importance of damage and insect-derived factors. Front. Plant Sci. 2021, 12, 709858. [CrossRef] [PubMed]

46. McCormick, A.; Gershenzon, J.; Unsicker, S.B. Little peaks with big effects: Establishing the role of minor plant volatiles in plant-insect interactions. Plant Cell Environ. 2014, 37, 1836-1844. [CrossRef]

47. Bruce, T.J.; Pickett, J.A. Perception of plant volatile blends by herbivorous insects-finding the right mix. Phytochemistry 2011, 72, 1605-1611. [CrossRef]

48. Ingber, D.A.; Christensen, S.A.; Alborn, H.T.; Hiltpold, I. Detecting the conspecific: Herbivory-induced olfactory cues in the fall armyworm (Lepidoptera: Noctuidae). Metabolites 2021, 11, 583. [CrossRef] [PubMed]

49. McCallum, E.J.; Cunningham, J.P.; Lucker, J.; Zalucki, M.P.; De Voss, J.J.; Botella, J.R. Increased plant volatile production affects oviposition, but not larval development in the moth Helicopverpa armigera. J. Exp. Biol. 2011, 214, 3672-3677. [CrossRef]

50. Papanastasiou, S.A.; Ioannou, C.S.; Papadopoulos, N.T. Oviposition-deterrent effect of linalool—A compound of citrus essential oils-On female Mediterranean fruit flies, Ceratitis capitata (Diptera: Tephritidae). Pest Manag. Sci. 2020, 76, 3066-3077. [CrossRef]

51. D'Auria, J.C.; Pichersky, E.; Schaub, A.; Hansel, A.; Gershenzon, J. Characterization of a BAHD acyltransferase responsible for producing the green leaf volatile (Z)-3-hexen-1-yl acetate in Arabidopsis thaliana. Plant J. 2007, 49, 194-207. [CrossRef] [PubMed]

52. Loughrin, J.H.; Manukian, A.; Heath, R.R.; Tumlinson, J.H. Volatiles emitted by different cotton varieties damaged by feeding beet armyworm larvae. J. Chem. Ecol. 1995, 21, 1217-1227. [CrossRef]

53. McCormick, A.C.; Irmisch, S.; Boeckler, G.A.; Gershenzon, J.; Köllner, T.G.; Unsicker, S.B. Herbivore-induced volatile emission from old-growth black poplar trees under field conditions. Sci. Rep. 2019, 9, 7714. [CrossRef]

54. Wei, J.; Kang, L. Roles of (Z)-3-hexenol in plant-insect interactions. Plant Signal. Behav. 2011, 6, 369-371. [CrossRef] [PubMed]

55. Hu, L.; Ye, M.; Erb, M. Integration of two herbivore-induced plant volatiles results in synergistic effects on plant defence and resistance. Plant Cell Environ. 2019, 42, 959-971. [CrossRef]

56. Frost, C.J.; Mescher, M.C.; Dervinis, C.; Davis, J.M.; Carlson, J.E.; De Moraes, C.M. Priming defense genes and metabolites in hybrid poplar by the green leaf volatile cis-3-hexenyl acetate. New Phytol. 2008, 180, 722-734. [CrossRef]

57. Alquézar, B.; Volpe, H.X.L.; Magnani, R.F.; de Miranda, M.P.; Santos, M.A.; Wulff, N.A.; Bento, J.M.S.; Parra, J.R.P.; Bouwmeester, H.; Peña, L. $\beta$-caryophyllene emitted from a transgenic Arabidopsis or chemical dispenser repels Diaphorina citri, vector of Candidatus Liberibacters. Sci. Rep. 2017, 7, 5639. [CrossRef]

58. Frank, L.; Wenig, M.; Ghirardo, A.; van der Krol, A.; Vlot, A.C.; Schnitzler, J.P.; Rosenkranz, M. Isoprene and $\beta$-caryophyllene confer plant resistance via different plant internal signalling pathways. Plant Cell Environ. 2021, 44, 1151-1164. [CrossRef]

59. Dicke, M.; Van Beek, T.A.; Posthumus, M.V.; Dom, N.B.; Van Bokhoven, H.; De Groot, A.E. Isolation and identification of volatile kairomone that affects acarine predatorprey interactions Involvement of host plant in its production. J. Chem. Ecol. 1990, 16, 381-396. [CrossRef] [PubMed] 
60. Kishimoto, K.; Matsui, K.; Ozawa, R.; Takabayashi, J. Analysis of defensive responses activated by volatile allo-ocimene treatment in Arabidopsis thaliana. Phytochemistry 2006, 67, 1520-1529. [CrossRef]

61. Shelly, T.E.; Nishimoto, J.I. Exposure to the plant compound $\alpha$-humulene reduces mating success in male Mediterranean fruit flies (Diptera: Tephritidae). Ann. Entomol. Soc. Am. 2015, 108, 215-221. [CrossRef]

62. Chen, S.; Zhang, L.; Cai, X.; Li, X.; Bian, L.; Luo, Z.; Li, Z.; Chen, Z.; Xin, Z. (E)-Nerolidol is a volatile signal that induces defenses against insects and pathogens in tea plants. Hortic. Res. 2020, 7, 52. [CrossRef] [PubMed]

63. Irmisch, S.; Clavijo McCormick, A.; Boeckler, G.A.; Schmidt, A.; Reichelt, M.; Schneider, B.; Block, K.; Schnitzler, J.P.; Gershenzon, J.; Unsicker, S.B.; et al. Two herbivore-induced cytochrome P450 enzymes CYP79D6 and CYP79D7 catalyze the formation of volatile aldoximes involved in poplar defense. Plant Cell 2013, 25, 4737-4754. [CrossRef]

64. Irmisch, S.; Clavijo McCormick, A.; Günther, J.; Schmidt, A.; Boeckler, G.A.; Gershenzon, J.; Unsicker, S.B.; Köllner, T.G. Herbivoreinduced poplar cytochrome P450 enzymes of the CYP 71 family convert aldoximes to nitriles which repel a generalist caterpillar. Plant J. 2014, 80, 1095-1107. [CrossRef]

65. Clavijo McCormick, A.; Irmisch, S.; Reinecke, A.; Boeckler, G.A.; Veit, D.; Reichelt, M.; Hansson, B.S.; Gershenzon, J.; Köllner, T.G.; Unsicker, S.B. Herbivore-induced volatile emission in black poplar: Regulation and role in attracting herbivore enemies. Plant Cell Environ. 2014, 37, 1909-1923. [CrossRef]

66. Lin, Y.; Qasim, M.; Hussain, M.; Akutse, K.S.; Avery, P.B.; Dash, C.K.; Wang, L. The herbivore-induced plant volatiles methyl salicylate and menthol positively affect growth and pathogenicity of entomopathogenic fungi. Sci. Rep. 2017, 7, 40494. [CrossRef] [PubMed]

67. Chambers, A.H.; Evans, S.A.; Folta, K.M. Methyl anthranilate and $\gamma$-decalactone inhibit strawberry pathogen growth and achene germination. J. Agric. Food Chem. 2013, 61, 12625-12633. [CrossRef]

68. Martins, C.H.; Cunha, B.P.; Solferini, V.N.; Trigo, J.R. Feeding on host plants with different concentrations and structures of pyrrolizidine alkaloids impacts the chemical-defense effectiveness of a specialist herbivore. PLoS ONE 2015, 10, e0141480. [CrossRef]

69. Pentinsaari, M.; Salmela, H.; Mutanen, M.; Roslin, T. Molecular evolution of a widely-adopted taxonomic marker (COI) across the animal tree of life. Sci. Rep. 2016, 6, 35275. [CrossRef] [PubMed]

70. Signoretti, A.G.C.; Nava, D.E.; Bento, J.M.S.; Parra, J.R.P. Biology and thermal requirements of Utetheisa ornatrix (L.) (Lepidoptera:Arctiidae) reared on artificial diet. Braz. Arch. Biol. Technol. 2008, 51, 447-453. [CrossRef]

71. Van den Dool, H.; Kratz, P.D. A generalization of the retention index system including linear temperature programmed gas-liquid partition chromatography. J. Chromatogr. 1963, 11, 463-471. [CrossRef] 